\title{
Lumen
}

Selected Proceedings from the Canadian Society for Eighteenth-Century Studies

\section{Dividing Lines: Surveyors and the Crossing of the Colonies}

\section{Pat Rogers}

Volume 31, 2012

URI : https://id.erudit.org/iderudit/1013066ar

DOI : https://doi.org/10.7202/1013066ar

Aller au sommaire du numéro

Éditeur(s)

Canadian Society for Eighteenth-Century Studies / Société canadienne d'étude du dix-huitième siècle

ISSN

1209-3696 (imprimé)

1927-8284 (numérique)

Découvrir la revue

Citer cet article

Rogers, P. (2012). Dividing Lines: Surveyors and the Crossing of the Colonies.

Lumen, 31, 41-64. https://doi.org/10.7202/1013066ar

Copyright (C Canadian Society for Eighteenth-Century Studies / Sociéte canadienne d'étude du dix-huitième siècle, 2012
Ce document est protégé par la loi sur le droit d'auteur. L'utilisation des services d'Érudit (y compris la reproduction) est assujettie à sa politique d'utilisation que vous pouvez consulter en ligne.

https://apropos.erudit.org/fr/usagers/politique-dutilisation/ 


\title{
Dividing Lines: Surveyors and the Crossing of the Colonies
}

\author{
Pat Rogers
}

University of South Florida, Tampa

\begin{abstract}
"Running a Line East and West," Dixon finally says, "for some Gentlemen who'll pay for something that looks good on a Map." "Lots of Boys for just a simple straight Line, ain't it?"
\end{abstract}

- Thomas Pynchon, Mason E Dixon (1997), chapter 62

Surveying has never counted as a very glamorous profession, but it has remained a useful and productive one over the course of human history. In particular, the opening up of America relied on the efforts of those who charted and parcelled up the land as the new country expanded, quite as much as it did on those of explorers and pioneers. This essay will try to justify the claims just made. It will begin with a rapid survey of the evolution of surveying, with a few brief reflections on boundaries. Second, it will consider the role of some prominent surveyors in the creation of British America during the colonial period. Throughout these two sections the main emphasis will lie on Anglo-Saxon practice, with no attention for example to the large part which the French, especially, and the Spanish played in other parts of the North American continent. Third, the essay will discuss the contentions over the border between Virginia and North Carolina in the decades before and after 1700, and will look at a famous work dealing with an expedition which was mounted in 1728 with the aim of settling some of the points which lay in dispute. This was The History of the Dividing Line by William Byrd II. A short conclusion will attempt to set out some reasons why surveying has been largely a hidden activity, 
and why we need to give it a more central place in our scheme of things when we assess the development of the colonies. ${ }^{1}$

We still lack a comprehensive social and cultural history of surveyors - who they were, how they were recruited, how they interacted, how they learnt their craft, who employed them, and what they actually did for the majority of their working life. By far the best account of the composition of the profession and the activities of its members can be found in Sarah Bendall's introduction to the second edition of The Dictionary of Land Surveyors. ${ }^{2}$ This provides a great deal of valuable quantitative data and plots the geographical spread of surveying across time. Bendall supplied interesting figures relating to the family origins of surveyors and their place of residence where established (in very many cases, this remains unknown). But of its nature this work, confined to Great Britain and Ireland, is able to supply little in its main entries beyond a listing of names and places, with some basic items of biographic information. The persons themselves remain mere individual atoms without any detectable DNA to enable us to form a general pattern. In fact, we have more thorough information about when and where the surveys were carried out than about most of the men who carried them out. For the rest, we must rely on scattered data concerning the most widely visible figures in the profession, often drawn from fugitive references in journals or letters. A very few celebrated individuals enter the margins of the story: thus the Royal Board of Ordnance employed the artist Paul Sandby, then a teenager, as a map-maker in the 1740 and appointed him as chief draughtsman for the project to

1. I am grateful to Don Nichol, the conference organizer, for many acts of kindness, not least when computer failings of my own making threatened to cause fatal damage to the presentation. I also wish to record thanks to the audience for useful criticisms and more especially to Kevin Berland, whose great knowledge of William Byrd II allowed him to suggest many improvements.

2. Sarah Bendall, Dictionary of Land Surveyors and Local Map-Makers of Great Britain 1530-1850, $2^{\text {nd }}$ ed. (London, 1997), 2 vols, 1: 1-65. The Dictionary was first edited by Peter Eden (1975-76). Bendall's thoroughly researched and skilfully presented materials might now be incorporated into a more general narrative: this would set her findings within a wider historiographic context and place surveyors among other emerging professions of early modern Britain. 
map the Highlands after the 1745/6 Jacobite rebellion. William Stukeley, the famous proto-archeologist, earns a listing in the Dictionary on the score of the work he performed in connection with his excavations and his tours of historic sites. He must be one of the few clergymen and perhaps even fewer physicians who qualified for recognition in this occupational category - at least by the eighteenth century.

Since the occupational status of surveyors remained hazy, with no established career path, their obliteration from history is the less surprising. They did not constitute a profession in the full sense for a very long time. They may have been apprenticed to a practitioner, often someone generally described as an engineer, but apart from the limited and specialized corps of military surveyors they had few obvious ways of establishing a socially recognizable profile. It was not until the nineteenth century that a fully professional status was achieved.

Disappointingly little is known of the education and background of most individuals who joined the profession. Some may have studied with the burgeoning group of mathematics teachers, whose work has been investigated by Eva Taylor and Larry Stewart among others. ${ }^{3}$ Among this group a good number, self-defined "philomaths," carried out such teaching themselves. Others, as indicated, may have entered the occupation by serving an apprenticeship, formal or otherwise, with a relevant professional such as an engineer. But there was of course no recognized qualification and, as we have seen, the status of surveyors remained in the dubious area lying between professionals and artisans. ${ }^{4}$ Sarah Bendall's tables reveal that the proportion of those with a university education was negligible, as was that of titled individuals. Among the most common occupational description of those who undertook surveys are builder, draughtsman, engineer and (late in the eighteenth century) architect, auctioneer and valuer. But there was also a sprinkling of disparate occupations - astrologers and "navigators" had almost totally vanished, leaving a handful of geologists, innkeepers,

3. See for instance E. G. R. Taylor, The Mathematical Practitioners of Tudor and Stuart England (Cambridge, 1954), and The Mathematical Practitioners of Hanoverian England 1714-1840 (Cambridge, 1966); and Larry Stewart, The Rise of Public Science. Rhetoric, Technology and Natural Philosophy in Newtonian Britain, 1660-1750 (Cambridge, 1992).

4. For the rise of new quasi-professions in the eighteenth century, augmenting the established "learned" professions, see Geoffrey Holmes, Augustan England: Professions, State and Society, 1680-1730 (London, 1982). 
instrument-makers, merchants and painters amidst the list. Nearsynonymous descriptions such as "measurer" were gradually squeezed out by the standard term "surveyor." So far I have found no female surveyors in the period - but then only a tiny number of women were able to gain entry into the profession anywhere in the world until the last few decades.

Notoriously the roads of Britain were generally no better in 1700 than they had been under Roman occupation, a millennium and a half before. The occupying power had managed to set up an efficient road network, even though they had neither maps nor compasses, and for alignments the agrimensores had to use the primitive tool called a groma, a simple cross of wood with lead weights attached. By the time that the American colonies came into being, the instruments available were more numerous and much more sophisticated. But the people who wielded these implements remained largely anonymous. One thing we do know is that they were steadily growing in numbers throughout the seventeenth and eighteenth centuries. After the Civil War, Bendall's tables reveal, there had been in the order of 600 surveyors who had begun to practice, from a base of only 200 in 1600 (the figures include Ireland). By 1730 the cumulative total had reached 2,000; and by 1783 it exceeded 5,000. ${ }^{5}$

What did the actual business of day-to-surveying amount to? Of course, the exact procedures depended on the precise job in hand: a drainage scheme might require different operations from a project to fix boundary lines, and measuring the coast presented different challenges from charting the glebeland of a parish. However, a good summary of ordinary practice appears in a work published in 1766 by Henry Sacheverell Homer, entitled An Essay on the Nature and Method of ascertaining the Specifick Shares of Proprietors, upon the Inclosure of Common Fields - one of the many tracts provoked by the enclosure movement. Although the advice given applies specifically to those who were intending to survey land destined for enclosure, it gives us a sense of the level of sophistication required to perform the appropriate tasks. Homer describes the steps to be taken in order to produce a "general survey," prior to enclosure, which involved finding out the dimensions and acreage of a given piece of land. This would be followed by a

5. See Bendall, Dictionary, 1: 26-51. 
"particular survey," computing the annual value of each acre to the landowner. The author proceeds:

The most approved Method of surveying and planning any Tracts of Land, is to measure the Outsides thereof from Station to Station with a Chain, taking Offsets from the straight Line at convenient Distances, where there is any Irregularity in the Figure; and at each Station also to mark the Angles or Bearings between the Lines; which is done either by Means of a graduated Instrument, as a Theodolite, Circumferentor, or Semicircle; or otherwise it is done by means of a Telescope and Plain Table; according to which Method the Lines are struck and set off by the Scale, upon a Card fixed to the Plain Table in the Field; and the Angles, thus drawn on the Spot, are determined to greater Certainty, than they can be by any graduated Instrument whatsoever. ${ }^{6}$

Homer (1719-91) was a clergyman, trustee of a large estate in Warwickshire, and most significantly a prominent enclosure commissioner. His work was praised by the great highway engineer John Loudon McAdam as the most useful he had encountered. The account here makes it clear that many surveyors in the middle of the eighteenth century were still using a conservative range of traditional instruments.

For the most part the operations took the form of small-scale surveys that possessed chiefly local significance. Rather than geographic or even chorographic in scope, their day-to-day activities clung to the description of minute topographic features. This detailed mapping, whether military or civil, led ultimately to the creation of the Ordnance Survey, and the popular "one inch to one mile" series, in recent times supplanted by the more detailed Explorer series on a scale of 1:25,000. Such richly informative maps have never been generally available in the Unites States, although some useful maps do exist that are aimed at hikers. Today people most often look first to a GPS system or to the Internet for directions. But zoom in far enough on Google Maps and the physical detail totally disappears. Even in a rural area nothing shows up beyond a virtual street map. As a result, when a remote location contains merely a single lane or track, the map may display nothing except two bare lines crossing the screen.

6. [H. S. Homer], An Essay on the Nature and Method of ascertaining the Specifick Shares of Proprietors, upon the Inclosure of Common Fields (Oxford, 1766), 53-54. 
No hills, woods, rivers, marshes, paths or ponds will be visible - let alone the sites of battlefields, historic houses, or other informative content to be found on the Ordnance Survey series. Of course the explanation for this disparity in national coverage lies to a great extent in the sheer magnitude of the American continent - a daunting feature of the landscape that confronted the surveyors of the colonies from the outset.

We are on safer ground when we turn to the identity of those who employed surveyors. In the medieval period, especially under the manorial system, a need arose for cadastral maps, showing "metes-andbounds" real property as a basis for legal title and registration of land, as well as to facilitate valuation and taxation. The most famous example is the Domesday Book. As time went on, a variety of crown or public offices needed to hold information of this kind. The church, like the Oxbridge colleges and various charitable bodies, held large swathes of property which had to be properly defined. Both clerical and lay impropriators set great store by their income from tithes, something that survived even the commutation of tithes in kind by an act of 1836 , a measure that itself required a large collection of new surveys to be undertaken. Numerous tithe surveys have been preserved in ecclesiastical and college archives. ${ }^{7}$ In addition the business community came increasingly to use this kind of resource, as did private landowners and (highly important in the colonial context) land speculators.

A boost in employment came with the rush of turnpike trusts after 1700 , initially in the teens and twenties of the new century. Each turnpike trust was required to have its own appointed surveyor, a paid office, along with a clerk and a treasurer: sometimes the roles were combined. This was a post ultimately held by McAdam prior to his introduction of major improvements in the construction of road surfaces. In some instances the trust gave the surveyor (usually paid something like $£_{25}$ per year) the contract for road improvements that he recommended, a system with obvious potential for corruption, but such a practice declined over the course of time. It looks as if the turnpike trust on occasions nominated a local worthy with no obvious

7. The importance of these documents was first recognized by Sir John Clapham: see his article, "Tithe Surveys as a Source of Agrarian History," Cambridge Historical Journal, 1 (1924): 201-08. The fullest modern treatment is Roger J. P. Kain and Hugh C. Prince, The Tithe Surveys of England and Wales (Cambridge, 1985). 
training in engineering or allied disciplines, and at first the salaried officials were probably very little more competent in highway engineering than the parish surveyors of highways, annually elected, who supervised the inadequate road network operating outside the turnpike system. ${ }^{8}$

Equally the spread of parliamentary enclosures prompted a surge in demand for new maps. Much new detail regarding the men who provided these can be found in an excellent book by Roger J. P. Kain, John Chapman and Richard R. Oliver, published in 2004. Despite the fact that the authors have been able to put together a very long list of surveyors who worked on these projects, these individuals remain surprisingly obscure, "often shadowy figures not named in the documents." It was the local commissioners who stood in the limelight.9 Unsurprisingly, a large corpus of practical manuals appeared in increasing numbers over the course of the seventeenth and eighteenth centuries. A representative example out of many would be a book by Thomas Breaks, A Complete System of Land-surveying, both in Theory and Practice, containing the best, the most Accurate, and Commodious Methods of surveying and planning of Ground by all the Instruments now in us: To this Work is annexed, a True and Correct Table of the Logarithms of all Numbers (Newcastle upon Tyne, 1771). The first wholly American textbooks, it is worth adding, date from late in the century, such as Samuel Moore's Accurate System of Surveying, published in Litchfield, Connecticut, in 1796.

We should note that some maps have survived in legal records rather than in more obvious places such as cadastral archives. Naturally property disputes could only be settled in many instances by reference to ground plans. Legal title was sometimes established by means of conventional phrases such as "10 acres more or less," a formula still in use. For tenants a quarter of an acre more or less might be the difference between survival and failure, if it involved things such as a right of way, access to watercourse and the like. We have only to think of

8. A large body of useful information on these topics is preserved by Sidney and Beatrice Webb, English Local Government: The Story of the King's Highway (London, 1913).

9. See Roger J. P. Kain, John Chapman and Richard R. Oliver, The Enclosure Maps of England and Wales, 1595-1918 (Cambridge, 1994), 198-202. For a list of surveyors, see 205-90. 
Maggie Tulliver's father in The Mill on the Floss to realise how easily seemingly minor disagreements over such matters might escalate into vexatious and expensive lawsuits. Lawyers, by the way, seldom figure in the list of working surveyors.

This is not the place for a full description of historic surveying equipment. ${ }^{10}$ Here it is enough to note a few technological and observational landmarks. The activity goes back to Sumerian times and had been considerably developed in ancient Greece and, especially, Rome. For our purposes the most important later innovations start with the evolution of the magnetic compass in western Europe around the twelfth century. Techniques of triangulation were introduced from Italy around 1530. Leonard Digges gave the first full description in English of the theodolite in 1571, while what became perhaps the most basic tool, the plane table, was not so described until 1690 - though it may have been used earlier. The bubble spirit level came into general use in Britain around the same time. The perambulating wheel is mentioned by Stukeley and must have been in use by the end of the seventeenth century (its operator nicely described as a perambulator). OED defines it as "a machine for measuring distances, consisting of a large wheel trundled by a handle along the ground, with attached clockwork and dial for recording the revolutions." Meanwhile the other basic implement, the measuring chain, had already become well established. It was the chain developed by Edmund Gunter in 1620 that became the instrument of choice. This device also helped to fix the fundamental units of mensuration more solidly than ever before. Gunter's chain consisted of 100 links to form a length of 22 yards, with a brass ring marking off each tenth link.

The units here have their origins in Anglo-Saxon England, although initially it was the rod (or pole or perch, as the older reference books used to have it) which was most important. This was finally set as the statute rod of $161 / 2$ feet, or one quarter of a chain. At the same time the statute acre, designed to supplant the "customary" acre which varied in size across local areas, was defined as 160 square rods, one of the measurements confirmed by an act of Edward I in

10. Good work on this subject has recently been done in organs such as the Bulletin of the Scientific Instrument Society. For an account of major developments, see A.W. Richeson, English Land Measuring up to 1800: Instruments and Practices (Cambridge, MA, 1966). 
1305. ${ }^{11}$ However, as time went on, especially from the sixteenth century, greater significance became attached to the link itself (7.92 inches) and the chain, a hundred times larger at 66 feet. A statute acre now becomes more easily identified in almost metric terms as 10 square chains (or 100,000 square links), most simply envisaged as a strip of land in the open fields system that measured 220 yards by 22 yards. ${ }^{12}$ Notionally, too, this was the amount of land that a single yoke of oxen could plough in a day. It comes as a shock to realize that the acre, which seems the quintessential unit of property, is really nothing more than a derivative of these measurements of length. We have so many phrases such as "God's little acre," and so many historic or literary allusions such as Voltaire's caustic reference to "a few thousand acres of snow," General Sherman's forty acres and a mule, or the Hundred Acre Wood in Winnie the Pooh. It is quite hard to accept that this hallowed term, with its ancient cognates in Greek ồ $\gamma \rho$ ó $̧$ and Latin acer, is truly no more than a back-formation from humdrum links and chains. But, be that as it may, it was the unit with which British surveyors grappled on a daily basis, until European legislation just before and after the millennium decreed the substitution of the hectare. The death throes of the acre were finally set in motion by a recent European Union directive, which banned the sale or registration of land other than by hectares from 1 January 2010.

11. The mile also remained a moveable feast until the statute mile (eight furlongs, that is eighty chains or 1760 yards, a length first recorded in the early sixteenth century) was standardized by an act of Elizabeth I in 1592. Even after this, the "old English" mile (about a quarter of a mile longer than the statute length) did not expire overnight, and local customary units survived in some places for generations. The longer Scottish and English miles were still in use as late as the eighteenth and nineteenth centuries.

12. Alternatively, of course, one furlong by one chain. The furlong is of Germanic origin and originally designated one furrow of ploughland. But the furlong, in modern times 220 yards, was variable in length in earlier centuries, and it has now been relegated from general use, except in horse-racing. The once standard 220 yards race in track and field athletics has long been supplanted by its metric equivalent. Although a cricket pitch remains fixed at 22 yards, it seems at no time to have been defined as a chain in length. 


\section{II}

It was far from the case that surveyors passed all their time fixing boundaries. They might be required, for example, to establish the internal dimensions of a property, to identify the best site for a bridge, or to confirm the location of physical features. However, the fiercest disputes tended to surround the exact course of dividing lines, which in practice they had to ratify if not to create.

In the colonies they often did this by drawing straight lines, whether in the remote mountains and swamps, or along the grids of the growing urban environment. The novelty of the New World, self-evidently, is inscribed in the plumb lines that mark off so many states and counties in America. This contrasts sharply with the higgledy-piggledy shapes that are found in long settled areas, such as the départements of France whose outline was defined by the bends of a winding river. Straight lines are strange things: they defy nature as they cut across hills and water-courses, yet they instigate new actualities, reifying the visible break between adjoining properties. They inspire conflicting emotions. You can feel cheated because a resident on the opposite side of some arbitrary boundary pays less tax than you do. At the same time their apparently random nature can cement relationships, on the principle that good fences make good neighbours. In this sense the work of surveyors was calculated to reduce friction, and so it turned out in a remarkable number of cases.

The well-known writer on natural history and environmental issues, Richard Muir, has made some relevant observations here:

Boundaries are less a part of life than once they were. In modern England, people have a vague awareness of local government territories - though the most critical boundaries for many are those defining school catchment areas. Vital issues of worship, tenure, obligation and fealty are no longer spatially defined by revered boundaries.... Formerly, however, people were highly conscious of authorities and their jurisdictions and well rehearsed in the disposition of local boundaries. These lines in the landscape defined the patterns of day-to-day life.

Boundaries serve both instructive and symbolic roles. When manifest to the onlooker in the form of ditches, banks, hedgerows and so on, they symbolise a divide that has been negotiated, imposed or claimed and perhaps, if erosion and repair are evident, hallowed by time as well. At 
the same time, these and other constructions express the territorial claim of a society or dynasty. ${ }^{13}$

Boundaries, of course, can be permeable or impermeable. Surveyors had no policing role: they were not gatekeepers or border guards, as they simply drew the lines and let others enforce any constraints or to impose any ideological (as opposed to physical) meaning on the division. While the long accreted symbolism described by Muir was largely absent in the colonies, except perhaps for the Native American population, the markers that surveying instruments laid down on the landscape would have important consequences for the pattern of life experienced by men and women in the New World.

\section{III}

Indeed, surveyors played a unique role in the construction of colonial identity. That generalization holds, even though the separate states had their own regulations and practices. Relevant to the purposes of this discussion, Virginia had its own particular way of establishing title to land. By 1642 the colony had introduced a legal obligation for all surveyors to "deliver an exact plott [plat, that is cadastral plan] to each parcel surveyed and measured." Exactitude was indeed a problem, since in seventeenth-century America Gunter's chain, already the implement of choice in Britain, had only just begun to gain a foothold. "When land was thought of as limitless," Kain and Baigent remind us, "there was little incentive to accuracy." A crucial feature of the system in use in colonies such as Virginia was the custom by which the individual would "locate and settle land prior to survey [italics added]," as well as the tendency for tracts "to be patented in relatively large blocks." Both these practices helped to mould the shape of colonial expansion, and equally they gave an almost unprecedented significance to the work of surveyors who followed behind those opening up the land.

Another consequence of the requirement to produce a "plat" is the survival of a large number of estate maps. Over time their reliability

13. Richard Muir, The New Reading of Landscape: Fieldwork in Landscape History (Exeter, 2000), 69. 
increased as surveyors adopted more modern techniques of observation and mensuration. To cite Kain and Baigent once more, "Some Virginia land plats... seem also to have acquired the symbolic meaning of English estate maps of this time as icons of the capitalist land-owning system transplanted from an England where wealth and social standing [are measured] by acres of land."14 The example cited is a plan drawn in 1701 to delimit the Westover plantation of William Byrd I. As we shall see, members of the Byrd family were among the most acquisitive of Virginian land speculators. The lines of their property assuredly represented, in Muir's terms, evidence of a territorial and even dynastic claim.

The importance of this work has been too easily discounted because of a fundamental category error. Surveyors do not in general do exploration; and we assume that the first people in the field, whether land-grabbers, traders or pedlars, were responsible for opening up America. But this is to confuse discovery of a given area with full economic and social exploitation. Neither the East nor the West was won until someone had drawn stable lines to mark off townships and define properties - and these tasks were not carried out by the first adventurers or carpet-baggers.

What of the individuals who took on this important and frequently arduous work? By the late 1720 s the occupation seemed to offer good career opportunities, as we can judge from comments in Benjamin Franklin's Autobiography. The young Franklin had travelled to Burlington, New Jersey, where he met the local surveyor-general:

[He] was a shrewd, sagacious old man, who told me that he began for himself, when young, by wheeling clay for the brickmakers, learned to write after he was of age, carried the chain for surveyors, who taught him surveying, and he had now by his industry acquired a good estate. ${ }^{15}$

One of the most influential practitioners in this period was Peter Jefferson (1709-57), father of Thomas. There was already a family tradition, since Peter's grandfather had himself served as a surveyor of the

14. Roger J. P. Kain and Elizabeth Baigent, The Cadastral Map in the Service of the State: A History of Property Mapping (Chicago, 1992), 269-73. Some useful background is supplied by Sarah Hughes, Surveyors and Statesmen: Land Measuring in Colonial Virginia (Richmond, VA, 1979).

15. Benjamin Franklin's Autobiography, ed. W. B. Cairns (New York, 1919), 64. 
roads. Growing up near what is now the city of Richmond, Peter came to know some important figures associated with surveying, most notably William Mayo, who would accompany William Byrd on the expedition to fix the state border in 1728 . He may have joined Mayo on surveying projects and is thought to have been taught mathematics at William and Mary College by Joshua Fry. ${ }^{16}$ Subsequently Fry (16991754), who like Mayo had been born in England, was one of those who combined with Jefferson to form the Loyal Land Company, which acquired 800,000 acres towards the Appalachians. This huge tract of land had its southern end at the dividing line between Virginia and North Carolina, and it was Jefferson and Fry who extended the boundary charted by Mayo in 1728. Later Peter and Fry investigated the Northern Neck of the state. The first outcome was a map of the line which appeared in Williamsburg in 1749, and the second was the socalled Jefferson-Fry map of 1751, the most famous such chart of the colony in pre-Revolutionary days. Peter served as surveyor of the recently formed county of Goochland, and acquired a tract of 1,400 acres he named Shadwell plantation, just to the east of what would become modern Charlottesville. It was this move which ensured that his son Thomas would form his lifelong association with the district.

Among the remarkable array of his talents, Thomas Jefferson would not have claimed the professional skills as a surveyor that Peter displayed. However, if his crowded life had allowed him the opportunity, there is little doubt that he could have prospered in this field too. The evidence lies in such things as the maps he drew of his own estates, such as a plat of Monticello prepared in 1794; his careful account of the estates in England that he visited with John Adams in 1786, totting up in great detail the acreage of given features in a landscape; and his supervision of the design of the new capital city of Washington. ${ }^{17}$ However, the most obvious clue might be found in his Notes on the

16. On Fry, see George W. Frye, Colonel Joshua Fry of Virginia and some of his Descendants and Allied Families (Cincinatti, OH, 1964).

17. On these three matters see respectively Frederick Doveton Nichols and Ralph E. Griswold, Thomas Jefferson: Landscape Architect (Charlottesville, 1978), 90-123; Edward Dumbauld, "Jefferson and Adams' English Garden Tour," in Jefferson and the Arts: An Extended View, ed. William Howard Adams (Washington, DC, 1976), 135-57; and Paul F. Norton, "Thomas Jefferson and the Planning of the National Capitol," in Adams, ed., Jefferson and the Arts, 191-232, along with Nichols and Griswold, Landscape Architect, 22-75. 
State of Virginia (1784), which begins with "an exact description of the limits and boundaries of the state of Virginia." The first straggling sentences of this expansive text concern the precise boundaries of the former colony, and the author takes the opportunity to mention Mason and Dixon twice by name. We might note the concluding words of this first paragraph, as it underlies Jefferson's aim throughout his Notes to equate America with its European forebears: "This state is therefore one-third larger than the islands of Great Britain and Ireland, which are reckoned at 88357 square miles." ${ }^{18}$ Who can doubt that Thomas had the genes of a surveyor passed on to him by his father?

Rather later than Peter Jefferson comes another figure associated with the founding fathers, Benjamin Latrobe (1764-1820), often described as America's first architect. Like many of the earlier colonial surveyors, he was born in England and worked on canals and river navigation before emigrating first to Virginia and then to Philadelphia. His contacts with Thomas Jefferson and Aaron Burr helped him to gain the commission to design the Capitol building among other projects in Washington. Also active in this period was a striking and still too little known figure in the story, Benjamin Banneker (1731-18o6), one of the first African-Americans to make his mark in an amazing diversity of fields - astronomy, mathematics, horology, and the making of almanacs. In 1791 he was appointed as the assistant to Andrew Ellicott (1754-1820), the most important surveyor of the time, in mapping the new Federal Territory, that is the heart of today's District of Columbia. The terrain covered ten square miles - the kind of scale on which some of the most momentous episodes in the history of surveying have taken place. Banneker also corresponded with Thomas Jefferson. Clearly he was not a specialist or fulltime surveyor; but that is true of many others in the early history.

We can pass over Charles Mason and Jeremiah Dixon, who were Englishmen with a background in astronomy contracted to fix the border between the northern and southern states in 1763-68. Neither had any extensive dealings with the colonies after this expedition, although Mason returned to Philadelphia, the home of his friend Franklin, before his death in 1786 . But even this cursory list must

18. Thomas Jefferson, Notes on the State of Virginia, ed. William Peden (Chapel Hill, NC, 1995), 4-5. 
include the most celebrated individual among those who can truly be described as surveyors - that is George Washington. Before he ever embarked on his career as a soldier, planter, farmer, land speculator and, of course, statesman, Washington had shown his proficiency in surveying - indeed he undertook his first work across the Blue Mountains at the age of sixteen on behalf of the proprietor Lord Fairfax. By seventeen he had become surveyor for the new Culpepper County, and had begun some extensive forays into the Shenandoah Valley. In all, some 200 surveys are credited to Washington, of which more than half survive. During the French and Indian war as a lieutenant colonel of the Virginia Regiment he supervised military surveys, and while he obviously could not perform such work during the Revolutionary War he did appoint a Scottish engineer to the post of geographer to the Continental Army. Among his various land speculations, the one most relevant to this discussion is his investment in the Dismal Swamp Company, a venture to be described shortly.

The youthful Washington seems, as has been stated, "to have genuinely enjoyed surveying, which after all was far more than simply a way of keeping a young man's pockets full. In a society where the ownership of land was everything and where, from a few days' ride away, the wilderness stretched on seemingly forever, surveying was a vital tool for transforming the natural world into wealth." ${ }^{19}$ This observation can stand, but we should remember that land brought with it not just wealth but social prestige and a strong sense of identity with the local community. Nor was it only the wilderness which needed to be charted: surveying the recently settled area played an equally important role in establishing colonial geography.

\section{IV}

"I am but lately returned from a progress," William Byrd wrote to his friend Lord Orrery in 1728. "I have been employed as a commissioner for setting the bounds betwixt this colony and North Carolina. This

19. Robert F. Dalzell, Jr., and Lee Baldwin Dalzell, George Washington's Mount Vernon: At Home in Revolutionary America (New York and Oxford, 1998), 33. On Ellicott, the fullest source remains Catherine Van Cortlandt Matthews, Andrew Ellicott, His Life and Letters (New York, 1908, rptd 1997). 
was in obedience to an order of his late Majesty [George I], by which we were commanded to run a due west line from the north shoar of Corotuck Inlet, quit up to the Appalachian Mountains, which may be in distance about 300 miles." Byrd goes on to describe how the party found it necessary at their starting point to find the just magnetic variation, "which is much less than Dr. Halley's map makes it." ${ }^{20}$ So began a journey far less epic in scale than the Lewis and Clark expedition, but one that tells us almost as much about the way in which the American landscape was opened up. The outcome of this trip was not one but two narratives by Byrd, neither of which appeared in print for a very long time.

William Byrd II (1674-1744) has become better known in recent decades following the publication of several unpublished writings. These include the Secret Diary he kept between 1709 and 1712; his London Diary of 1717-21; the Commonplace Book that was edited for the first time in 2001; and his correspondence. In addition we have the diary of a journey he made around England in 1701, composed by his fellow-traveller Sir John Percival (1683-1748), later first Earl of Egmont. All of these possess considerable historical interest, but none perhaps ranks with the History of the Dividing Line, first published in 1841, or its more indiscreet alternative version, the Secret History, largely unknown until edited by William K. Boyd in 1929. ${ }^{21}$ The narrative seems to have been compiled by $173^{8}$, as its existence was known to the English naturalists Peter Collinson and Mark Catesby by that date. We might add that, more than half a century later, Thomas Jefferson saw the two versions of History and wished to see the account in print.

The disputes regarding the exact line dividing the two states took their origin from two grants made by Charles II to the proprietors of Carolina. The first, in 1663 , fixed the boundary along the latitude of $36^{\circ}$ North, but its successor in 1665 contained a crucial amendment. It

20. The Correspondence of the three William Byrds of Westover, Virginia 1684-1776, ed. Marion B. Tinling, 2 vols (Charlottesville, VA, 1977), 1: 174.

21. See William Byrd's Histories of the Dividing Line betwixt Virginia and North Carolina (Raleigh, NC, 1929). This edition has been reprinted by Dover (New York, 1967), with a new introduction by Percy G. Adams: this is the version I cite with the cue title "HDL." The Secret History is included in a Penguin anthology, Colonial American Travel Narratives, ed. Wendy Martin (Harmondsworth, 1994), 77-172. The most complete edition is now found in The Prose Works of William Byrd of Westover, ed. Louis B. Wright (Cambridge, MA, 1966). 
was now stated that the line should run from Currituck Inlet "on a Streight westerly line to Wyonoke Creek, which lys within or about the Degrees of thirty-six and thirty Minutes Northern Latitude; and so west in a Direct line as far as the South seas" (HDL 324). This absurd claim plainly states that the line would run all the way to the Pacific, a totally unrealistic piece of vainglory even if the French possessions had not blocked the way. By this revision of the grant the border of Carolina moved northwards to include a strip of around 30 miles. In any case the exact identity and location of Wyonoke Creek remained obscure: together with the ambiguous legalese of the patent, this made controversy inevitable. The two colonies made an attempt in 1710 to establish the boundary more firmly, but squabbles among the commissioners and inadequate equipment ensured that this would fail. A compromise was patched together in 1715 by the respective governors, Alexander Spotswood and Charles Eden, but this merely delayed the inevitable. So arose the need for a more thorough survey in 1728 in order to draw the line to the satisfaction of both sides, once and for all.

Seven commissioners were nominated by the two colonies, which each provided two surveyors. The most experienced among this latter group, and the only one fully trusted by Byrd as the leading Virginian commissioner, was someone already mentioned: William Mayo (16851744), an Englishman who had come to prominence with a map of Barbados and would play a major role in the remapping of Virginia in years to come, as well designing the layout of Richmond, where he owned a considerable portion of land. The party included a chaplain who, they hoped, might convert "savages" of any race. Completing the team were assistants who carried out the hard labour of lifting, portage and chain-carrying. On the first segment of the expedition they numbered twenty, on the second stage seventeen. Despite the largely menial nature of their work these men seem not to have been in any way crude or incompetent at their job: several of them, indeed were landholders and fully literate. A list of expenses shows that the total outlay was a suspiciously round sum of $£ 1,0 \circ 0$, with Byrd and a fellow commissioner paid $£_{142}$, while the disruptive third commissioner from Virginia, Richard Fitzwilliam, who left the expedition early with the Carolinians, got £94. The chaplain received $£_{20}$, and each of the surveyors $£_{75}$ - a far from generous fee, relatively. As for the men, their combined share stood at $£_{277}$ for wages, along with the 
added expense of $£_{44}$, to cover " 7 horses lost," suggesting they brought their own horses.

The party left the Atlantic coast in early March and over the course of the next five weeks surveyed the line to a distance of 73 miles. Activity was resumed in September, and just over 100 more miles were completed by the joint group. At this point the Carolinian element decided that the job was sufficiently done and made their way home along with Fitzwilliam. Byrd and the remaining Virginians stuck it out for a further 64 miles, reaching almost to the foothills of the Appalachians. They then turned round and began the journey back in November. Byrd calculated their full itinerary as 243 miles. As the head of a leading family in the colony, as well as a travelled and well educated gentleman, he naturally possessed the strongest voice in most decisions; but it does not need saying that Mayo and his colleague Alexander Irvine played the critical role as far surveying went.

The History, in either guise, is no longer an obscure work. However, scholars have tended to concentrate on a few familiar aspects of the text. Most insistently they have paid attention to Byrd's descriptions of the natural world, which do indeed rival the account of William Bartram as an evocation of the flora and fauna of early America. ${ }^{22}$ Other students have looked at the medical aspects of the book; at the politics of the intercolonial dispute; at Byrd's own biography and psychology, as revealed in the text; at race, because the party encountered many blacks and Native Americans; and at gender, since the Secret History reports numerous encounters with local women. What has been neglected to a remarkable degree is the whole raison d'etre of the trip, and along with that the practicalities of surveying. ${ }^{23}$ These issues will be addressed more fully in Kevin Berland's forthcoming edition for the Omohundro Institute of early American History and Culture.

22. See, for example, Stephen Conrad Ausband, Byrd's Line: A Natural History (Charlottesville, 2002), which includes selections only from those entries "relevant to a study of the natural history of the area" (15).

23. A telling instance: when Louis B. Wright and Marion Tinling included the Secret History in their edition of The London Diary (1717-1721) and Other Writings (New York, 1958), they abridged the text, seeking to retain "those passages that have the greatest literary and human interest." In practice this means omitting segments "describing the delays of the surveyors in the Dismal Swamp," detailing "the daily routine of the surveyors," or setting out "routine difficulties." Why this material lacks human interest is not immediately obvious. 
It takes only a cursory examination of the text to see that, despite his other spheres of interest, Byrd is constantly preoccupied with the demands of the survey itself. There is space to quote only a few brief examples here: they could be multiplied at least ten times. On 5 October he writes:

This day we met with such uneven Grounds, and thick Underwoods, that with all our Industry we were able to advance the Line but 4 miles and 312 Poles. In this small Distance it intersected a large stream four times, which our Indian at first mistook for the South Branch of Roanoke River; but, discovering his Error soon after, he assur'd us 'twas a river called Hicootomony, or Turkey-Buzzard River, from the great number of those unsavoury birds that roost on the tall trees growing near its banks. ${ }^{24}$

Four days later he records:

The Thickets were hereabouts so impenetrable, that we were obliged, at first setting off this Morning, to order four Pioneers to clear the way before the Surveyors. But, after about 2 Miles of these rough-woods, we had the Pleasure to meet with Open Grounds and not very uneven, by the help of which we were enabled to push the Line about 6 Miles. ${ }^{25}$

More often, the story is of severe terrain, steep hills, heavy forests, and other obstacles to the surveyors in their work. Byrd seldom omits for long to keep up a record of the progress made along the line. A representative passage takes a form like this: "We were so perplexed with this Serpentine Creek, as well as in Passing the Branches of the Irvin, (which were swell'd since we saw them before,) that we could reach but 5 Miles this whole day." ${ }^{26}$

A final longer example may suffice:

The Surveyors enter'd Early upon their Business this morning, and ran the Line thro' Mr. Eyland's Plantation, as far as the Banks of North River. They passt over it in the Periauga, and landed in Gibbs' Marsh, which was a Mile in breadth, and tolerably firm. They trudged through this Marsh without much difficulty as far as the High Land, which promised more Fertility than any they had seen in these Parts. But this firm Land lasted not long before they came upon the dreadful Pocoson

24. HDL, 168.

25. HDL, 188.

26. HDL, 250. 
they had been threaten'd with. Nor did they find it one Jot better than it had been painted to them. The beavers and otters had rendered it quite impassable for any creature but themselves.

Our poor Fellows had much ado to drag their Legs after them in this Quagmire, but disdaining to be baulkt, they cou'd hardly be persuaded from pressing forward by the Surveyors, who found it absolutely Necessary to make a Traverse in the Deepest Place, to prevent their Sticking fast in the Mire, and becoming a Certain Prey to the Turkey-Buzzards.

This Horrible Day's Work Ended two Miles to the Northward of Mr. Merchant's Plantation, divided from N W river by a Narrow Swamp, which is causway'd over. We took up our Quarters in the open Field, not far from the House, correcting, by a Fire as large as a RomanFuneral-Pile, the Aguish Exhalations arising from the Sunken Grounds that Surrounded us. ${ }^{27}$

For large portions of the text we are similarly close to the ground, observing the physical details and the perils faced by the team as they attempted to extend the line westward.

It is easy to understand why attention has been distracted from such matters. Byrd has a genuine talent for comic observation, his setpieces are both spirited and engaging, and he excels in denunciations of the lazy inhabitants of "Lubberland" on the North Carolina side of the border. However, the History is finally no more than a mock epic: compared with the journeys of Lewis and Clark, it concerns only a short traverse of the eastern seaboard, rather than a heroic anabasis through the heart of the continent. Yet, more precisely than any of the journals that describe the later expedition, it conveys what surveying was like on a day-to-day level.

This holds true particularly when we look at the section covering the biggest challenge of the entire journey - crossing the Dismal Swamp. It is somewhat disconcerting to find that Byrd drafted a petition to the crown, proposing the formation of a company to drain the swamp, staff it with slave labour, build roads and canals across the claimed land, and set up farms. A return of 1,000 per cent within a decade was implausibly envisaged. In the text of the History Byrd weighed up the potentialities:

27. HDL, 52 . 
We are not yet acquainted with the precise Extent of the Dismal, the whole haveing never been Survey'd; but it may be Computed at a Medium to be about 30 Miles long and 10 Miles broad, tho' where the Line crost it, twas compleatly 15 Miles wide. But it seems to grow Narrower towards the North, or at least does so in many Places. The Exhalations that continually rise from this vast Body of mire and Nastiness infect the Air for many Miles round, and render it very unwholesome for the Bordering Inhabitants. It makes them liable to Agues, Pleurisies, and many other Distempers, that kill abundance of People, and make the rest look no better than Ghosts. It wou'd require a great Sum of Money to drain it, but the Publick Treasure cou'd not be better bestow'd, than to preserve the Lives of his Majesty's Liege People, and at the same time render so great a Tract of Swamp very Profitable, besides the advantage of making a Channel to transport by watercarriage goods from Albemarle Sound into Nansimond and Elizabeth Rivers, in Virginia. ${ }^{28}$

In the early 1760 a group of investors including George Washington bought a large tract in the swamp with the idea of putting Byrd's plans into practice. The Dismal Swamp Company's affairs soon grew tangled, and not until the start of the next century did they start to make some return on their capital. ${ }^{29}$

Essentially the area had never been surveyed, as Byrd points out:

Tis hardly credible how little the Bordering inhabitants were acquainted with this mighty Swamp, notwithstanding they had liv'd their whole lives within Smell of it. Yet, as great Strangers as they were to it, they pretended to be very exact in their Account of its Dimensions, and were positive it could not be above 7 or 8 Miles wide, but knew no more of the Matter than Star-gazers know of the Distance of the Fixt Stars. . . In short, we saw plainly there was no Intelligence of this Terra Incognita to be got, but from our own Experience. For that Reason it was resolv'd to make the requisite Dispositions to enter it next Morning. We allotted every one of the Surveyors for this painful Enterprise, with 12 Men to attend them. Fewer than that cou'd not be employed in clearing the way, carrying the Chain, marking the Trees, and bearing the necessary Bedding and Provisions. Nor wou'd the Commissioners themselves have

28. HDL, 84-86.

29. See Charles Royster, The Fabulous History of the Dismal Swamp: A Story of George Washington's Times (New York, 1999), for an erudite and entertaining account of the many "schemers and dreamers" who attempted to make a profit from the Swamp. 
Spared their Persons on this Occasion, but for fear of adding to the poor men's Burthen, while they were certain they cou'd add nothing to their Resolution. $^{30}$

In the event, while the commissioners took a relatively comfortable walk, dryshod, around the marshes, the surveyors ploughed doggedly through the heart of the Swamp. It was a herculean task. One day the line progressed by no more than one mile, 64 chains. At one point there were genuine fears that they might have perished along with the support staff, but eventually one of the group emerged unscathed, although in "a very tatter'd condition," to report that the "Dismalites" were all safe (HDL 82). It is one of the moments in the History when we realise just how arduous, time-consuming and labour-intensive surveying the new continent could be.

\section{V}

Why choose Byrd's account? He was not himself a surveyor, after all. Nevertheless, his History gives some of the best insights into what actually went on in the profession, for men like William Mayo - especially during a protracted expedition.

In fact, surveyors form part of the hidden underbelly of eighteenthcentury society - people like land agents, auctioneers, marriage brokers, accountants - on whom the aristocracy, the gentry, and increasingly the business community depended. They did not routinely publish their work. In most cases it was aimed at a single client, whether a public body, an institution of the crown, a state, a county, a parish, or a particular landowner. Sometimes they may have given no more than an oral report, when asked to check the true extent of a given tract. Their work was instrumental, as they did not commonly strive to produce beautiful objects, or to settle the fate of nations. Their labours did generate records which could be adduced in disputes, but otherwise their work has remained largely invisible unless a dedicated researcher has brought it out of the archival shadows. So surveying has remained a subterranean world, whose doings were very important to those involved, but largely unvisited by most historians.

30. HDL, 6o-62. 
Surveyors did more than measure, they defined space. The comment that Pynchon's character makes about the work of Mason and Dixon reflects a common misapprehension, resting on the assumption that anyone can stick a few poles in the ground and sketch out a reasonably straight line on the ground. In addition the surveying profession was responsible for a great deal of the naming of places. Creating toponyms is one of the main ways in which an area of land is brought under control: defined, made actual, admitted to the locality. If we unpack Simon Schama's phrase about "landscape and memory," we might reflect how much of our sense of place is connected to people, events or associations spelt out in the names of roads, paths, streams, woodlands and other features. ${ }^{31}$ Many of these were first written down by surveyors, on the basis of folk memories, and others were actually invented during the course of a survey. And it was William Mayo's patron William Byrd, we recall, who bestowed a name on Richmond and Petersburg in Virginia.

The CSECS conference in 2010 abundantly showed that huge shifts occurred on a continental and oceanic level in the eighteenth century, as a result of war, colonization, emigration, demographic variations, and resettlement. These seismic events were registered primarily by cartographers working on the grand scale. But most people spent much of their lives in a more confined space, their lives defined - in the colonies as in old Europe - by the bounds of a farm or the contours of a small urban neighbourhood. Their horizons often extended little beyond God's little acre. They did not inhabit a global village: we might almost say that for the majority of the population in the early modern era the village was their globe. This was the level at which the run of surveyors worked: for routine tasks, their maps were commonly drawn on a scale from about an inch to two chains up to one of an inch to twelve chains.

William Byrd's Secret History ends with an appendix setting out the distance covered between places that the party had passed along the dividing line. The very last entry reads:

31. See Simon Schama, Landscape and Memory (London, 1996). Schama has some interesting brief comments on the survey of the Highlands after Culloden (466). 
To a Red Oak mark'd on 3 Sides with 4 Notches, \& the Trees blaz'd about it, on the East Bank of a Rivulet, suppos'd to be either a Branch of Roanoke, or Deep River. ${ }^{32}$

The distance from the previous point is reported as o:3:60, that a little more than three and a half furlongs (quarentenae). Byrd's data give us a valuable reminder. As well as the Atlantic, the Mississippi and the St. Lawrence, we need to keep in our minds the little rivulets that fed the mainstream of life in the eighteenth century, and the red oak that stood at the corner of someone's plot. These were the things that surveyors noted, measured, charted and named, day after day, mile after mile, chain after chain, link after link. 